\title{
Searching for Networks: Ecological Connectivity for Amphibians Under Climate Change
}

\author{
Felipe S. Campos, Ricardo Lourenço-de-Moraes, Danilo S. Ruas, Caio V. \\ Mira-Mendes, Marc Franch, Gustavo A. Llorente, Mirco Solé, Pedro Cabral
}

This is the author accepted manuscript of the following article published by Springer:

Campos, F. S., Lourenço-de-Moraes, R., Ruas, D. S., Mira-Mendes, C. V., Franch, M., Llorente, G. A., ... Cabral, P. (2020). Searching for Networks: Ecological Connectivity for Amphibians Under Climate Change. Environmental Management, 65(1), 46-61. [Advanced online publication on 12 december 2019]. Doi: https://doi.org/10.1007/s00267-019-01240-0, which has been published in final form at https://doi.org/10.1007/s00267-019-01240-0

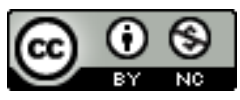

This work is licensed under a Creative Commons Attribution-NonCommercial 4.0 International License. 


\section{Searching for networks: ecological connectivity for amphibians under climate}

2 change

3

4 Felipe S. Campos ${ }^{1,2, *}$, Ricardo Lourenço-de-Moraes ${ }^{3}$, Danilo S. Ruas ${ }^{4}$, Caio V. Mira-

5 Mendes $^{4}$, Marc Franch ${ }^{5}$, Gustavo A. Llorente ${ }^{1}$, Mirco Solé6, Pedro Cabral ${ }^{2}$

6

$7 \quad{ }^{1}$ Departament de Biologia Evolutiva, Ecologia i Ciències Ambientals, Facultat de

8 Biologia, Universitat de Barcelona, 08028, Barcelona, Spain

$9 \quad{ }^{2}$ NOVA Information Management School (NOVA IMS), Universidade Nova de

10 Lisboa, Campus de Campolide, 1070-312, Lisboa, Portugal

$11{ }^{3}$ Programa de Pós-graduação em Ecologia e Monitoramento Ambiental (PPGEMA),

12 Universidade Federal da Paraíba, Campus IV - Litoral Norte, 58297-000, Rio Tinto, PB,

13 Brazil.

$14{ }^{4}$ Programa de Pós-Graduação em Ecologia e Conservação da Biodiversidade,

15 Universidade Estadual de Santa Cruz, 45662-000, Ilhéus, BA, Brazil

$16{ }^{5}$ CICGE - Centro de Investigação em Ciências Geo-Espaciais, Observatório

17 Astronómico Prof. Manuel de Barros, Universidade do Porto, 4430-146, Vila Nova de

18 Gaia, Portugal

$19{ }^{6}$ Departamento de Ciências Biológicas, Universidade Estadual de Santa Cruz, 45662-

20 000, Ilhéus, BA, Brazil

21

$22 *$ Corresponding author at: Departament de Biologia Evolutiva, Ecologia i Ciències

23 Ambientals, Facultat de Biologia, Universitat de Barcelona, ES-08028, Barcelona,

24 Spain. Phone numbers: +34 691388690 / +34 934021455 . 
ORCID: 0000-0001-7415-0202

\section{Abstract}

35 Ecological connectivity depends on key elements within the landscape, which can

36 support ecological fluxes, species richness and long-term viability of a biological

37 community. Landscape planning requires clear aims and quantitative approaches to identify which key elements can reinforce the spatial coherence of protected areas design. We aim to explore the probability of the ecological connectivity of forest

40 remnants and amphibian species distributions for current and future climate scenarios

41 across the Central Corridor of the Brazilian Atlantic Forest. Integrating amphibian

42 conservation, climate change and ecological corridors, we design a landscape ranking based on graph and circuit theories. To identify the sensitivity of connected areas to

44 climate-dependent changes, we use the Model for Interdisciplinary Research on Climate by means of simulations for 2080-2100, representing a moderated emission scenario within an optimistic context. Our findings indicate that more than $70 \%$ of forest

47 connectivity loss by climate change may drastically reduce amphibian dispersal in this region. We show that high amphibian turnover rates tend to be greater in the northeastern edges of the corridor across ensembles of forecasts. Our spatial analysis reveals a general pattern of low-conductance areas in landscape surface, yet with some well- 
connected patches suggesting potential ecological corridors. Atlantic Forest reserves are expected to be less effective in a near future. For improved conservation outcomes, we recommend some landscape paths with low resistance values across space and time. We highlight the importance of maintaining forest remnants in the southern Bahia region by drafting a blueprint for functional biodiversity corridors.

\section{$57 \quad$ Keywords}

Anura, Atlantic Forest, functional corridor, climate models, dispersal ability

\section{Introduction}

61

62 The implementation of Protected Areas (PAs) is among the most effective methods for long-term biodiversity conservation plans (Rodrigues et al. 2004), working as a key strategic tool in the development of environmental policies and efforts to sustain natural ecosystem processes (Le Saout et al. 2013; Laurance et al. 2014). The selection of PAs is often aimed to preserve either species of different taxonomic groups, conservation target species (e.g., threatened and/or endemics), or combinations of different abiotic conditions favourable to local ecosystems that will likely protect a wide range of biodiversity (Lawler and White 2008). Given that habitat loss is the most important

70 threat to species survival (Haddad et al. 2015), the protected sites chosen by decision71 makers can determine which species will be able to survive in the area (Jenkins et al.

72 2015). The effectiveness of these selected sites in reaching conservation goals depends on how many of the target species are represented in a given area (Dietz et al. 2015).

74 Although generally unseen, amphibians are the most abundant land vertebrates in humid tropical forests (Stebbins and Cohen 1995). Globally, they include over 7,000 species 
of frogs (Anura), 700 species of salamanders (Caudata) and 200 species of caecilians

77 (Gymnophiona) (Frost, 2019). However, amphibian conservation actions have

78 overlooked the biodiversity patterns in an effective conservation policy (Campos et al. 2017).

Among all vertebrates, amphibians are the group with the most species (24\%) whose geographical ranges are unprotected and not included in PAs (Nori et al. 2015). More than 2,000 amphibian species are listed as threatened by extinction, which makes them the most threatened vertebrate group worldwide (Stuart et al. 2004; IUCN 2018). Many reductions and extinctions of amphibians have occurred due to the habitat loss (Stuart et al. 2004; Becker et al. 2007; Ferreira et al. 2016), mainly in the Neotropical region, which harbours a significant amount of the global amphibian diversity (Young et al. 2004; Silvano and Segalla 2005; Becker et al. 2007). Amphibian conservation in fragmented landscapes is directly related to the establishment of protected areas and requires special management tools such as habitat restoration and management of forest patches, ensuring habitat quality and, hopefully, the permanence of the species (OchoaOchoa et al. 2009; Lourenço-de-Moraes et al. 2018). Therefore, compiling data about species distribution ranges is key to planning conservation actions (Verdade et al. 2012; Morais et al. 2013; Campos et al. 2017).

Conservation strategies aimed at protecting threatened amphibians were proposed by previous studies that highlighted parts of the Brazilian Atlantic Forest as high priority areas (e.g., Loyola et al. 2008; Campos et al. 2013; Lemes and Loyola 2013; Dias et al. 2014). In addition, some taxonomic groups of amphibians from small areas within the Atlantic Forest were identified as potential surrogates of biodiversity in Brazil (Campos et al. 2014). Species with access to mountainous regions may migrate to higher altitude areas with lower temperatures (Colwell et al. 2008), which in the case of 
101 the Atlantic Forest, should retain greater humidity due to better-preserved forest cover

102 (Ribeiro et al. 2009). However, the survival of threatened amphibians in fragmented

103 tropical landscapes is dependent on the integrity and persistence of their PAs(Urbina-

104 Cardona 2008; Ochoa-Ochoa et al. 2009; Lourenço-de-Moraes et al. 2019).

105 The economic growth policy in Brazil is widely based on the expansion of

106 agricultural frontiers (Ribeiro et al. 2009), directly affecting the availability and the

107 distribution of forest remnants in scattered private lands, which are gradually becoming

108 crop and pasture production areas (Tabarelli et al. 2004). Forest isolation can affect

109 many species' distributions by habitat loss, leading to long-term changes in the structure

110 of the remaining fragments (Metzger 2009; Lourenço-de-Moraes et al. 2018). This

111 factor means that the use of ecological connectivity metrics can be good indicators for

112 measuring the isolation of PAs and their ecosystem functions (Gurrutxaga et al. 2011).

113 Assessing ecological connectivity among PAs is becoming a relevant subject of

114 growing international effort in relation to nature conservation policies (Bennett and

115 Mulongoy 2006; Worboys et al. 2006). By using connectivity in planning, managers

116 attempt to avoid functional isolation of PAs (Carroll et al. 2004; Liang et al. 2018) and

117 mitigate the effects of climate change on the population structure of endemic species by

118 allowing for range shifts (Bennett and Mulongoy 2006; Triviño et al. 2018). Thus, an

119 understanding of future climate conditions is essential for predicting the effects of

120 habitat isolation and species range shifts. In an attempt to understand these effects,

121 modelling species responses to different climatic scenarios of environmental conditions

122 has proven to be an effective tool (Carnaval and Moritz 2008; Diniz-Filho et al. 2009;

123 Austin and Van Niel 2011; Araújo and Peterson 2012). Researchers are combining

124 environmental spatial data with ecological and evolutionary processes to predict how

125 species will shift their ranges in the future (Elith et al. 2010; Kearney et al. 2010; 
126 Martensen et al. 2017; Triviño et al. 2018; Lourenço-de-Moraes et al. 2019). Ecological

127 niche models (ENMs), also referred to as species distribution models (SDMs) (Peterson

128 et al. 2011; Rangel and Loyola 2012), have been increasingly used to estimate the

129 spatial ranges of species for future scenarios of climate change (Peterson et al. 2011).

130 These predictions may provide useful contributions to decision-making regarding

131 biodiversity conservation (Loyola et al. 2014).

132 Ecological implications of species tolerances to climate change are increasing

133 and contributing to a better understanding of how spatiotemporal connectivity

134 information can be incorporated into dispersal patterns (Bled et al. 2013). Climatic

135 change may alter species distributions (Pearson and Dawson 2003; Raxworthy et al.

136 2008), as well as significant species turnovers (Peterson et al. 2012). In this context,

137 ecological connectivity of forest landscapes is of paramount importance to ensure the

138 flow of species among potential climate refuges (Pearson and Dawson 2005).

139 Considering that climate change can aggravate environmental stresses from habitat loss

140 and fragmentation, there is high interest in maintaining ecological connectivity in

141 changing climates (Hamilton et al. 2016). However, only a few studies considered the

142 potential impact of climate change on the fragmentation of populations (Duan et al.

143 2016).

144 Ecological connectivity strategies depend not only on the existence of structural

145 connections between habitat patches but also on habitat suitability, stepping stones,

146 matrix permeability and the target organisms' responses to these elements (Tischendorf

147 and Fahrig 2000; Baum et al. 2004). Complex agroforestry systems are often used as

148 suitable habitats for different species across fragmented landscapes, also improving

149 dispersal pathways and connecting local species assemblages (Faria et al. 2007).

150 Advances in conservation biogeography have addressed many interactions between 
151 habitat suitability and species response, varying in complexity, realism and data

152 requirements (Franklin 2010). Graph and circuit theories are complementary methods

153 that have been used to provide efficient approaches for identifying biodiversity

154 corridors (McRae et al. 2008; Spear et al. 2010). While circuit theory models outline

155 high-conductance areas between patches (McRae et al. 2008), graph-based models

156 determine the optimal least-cost routes pairwise landscape distances (Urban and Keitt

157 2001). However, efficient ecological corridors must facilitate dispersal movements and

158 consider species life-history requirements (Rosenberg et al. 1997). In this context,

159 amphibians have been cited as highly appropriate species for examining landscape

160 effects on community structure, due to their relatively limited mobility, sensitivity to

161 dispersal barriers and strong microhabitat associations (Austin et al. 2002; Spear et al.

162 2005; Lee-Yaw et al. 2009).

163 To answer where the amphibian species could disperse in the face of climate

164 change, we assess how changing climate might affect the protected network

165 effectiveness for amphibian distributions. Here, we explore the probability of the

166 ecological connectivity of forest remnants and amphibian species for current and future

167 climate scenarios. Specifically, we aim at modelling the ecological connectivity to

168 represent forest remnants that most contribute to upholding amphibian connectivity in

169 the Central Corridor of the Brazilian Atlantic Forest, estimating the species turnover

170 between current and future amphibian species distributions. We evaluate if the PAs

171 network of this corridor safeguards amphibian species that occur in this region, testing

172 if this network can work as an effective biodiversity corridor for amphibians. Then, we

173 show the relationship between environmental variables and amphibian species

174 distributions across the protected network. We highlight the importance of maintaining

175 forest remnants in the main Atlantic Forest biodiversity corridor (i.e., the Central 
176 Corridor), suggesting implications for amphibian conservation planning and providing

177 new approaches on ecological connectivity in different climatic conditions. These

178 results may be useful as a tool for designing conservation strategies that incorporate the

179 effects of climate change and habitat fragmentation in a landscape planning approach.

180

$181 \quad$ Materials and Methods

182

183 Study area

184

185 The Atlantic Forest represents one of the five most important biodiversity hotspots on

186 Earth (Mittermeier et al. 2011). Originally, it covered around 1,500,000 km², of which

187 only about $12 \%$ (i.e., $194524 \mathrm{~km}^{2}$ ) still remains in Brazil, Paraguay and Argentina

188 (Ribeiro et al. 2009), corresponding to about 100,000 $\mathrm{km}^{2}$ of Brazilian forest remnants

189 (Tabarelli et al. 2005). Despite having high rates of habitat loss (Teixeira et al. 2009),

190 which is one of the main factors driving amphibians to extinction (Stuart et al. 2004;

191 Becker et al. 2007), the Atlantic Forest is the leader biome in amphibian diversity in

192 Brazil (Haddad et al. 2013), accounting more than 50\% of all Brazilian amphibian

193 species (Haddad et al. 2013).

194 We focused our study on the Central Corridor of the Brazilian Atlantic Forest,

195 which comprises about $8 \%$ of the total biome area (i.e., $7,913.42 \mathrm{~km}^{2}$ ), covering $14 \%$ of

196 forest remnants (SOS Mata Atlântica and INPE 2015). Here, we used the term Brazilian

197 Atlantic Forest to refer to the forest remnants map provided by SOS Mata Atlântica and 198 INPE (2015).

199

$200 \quad$ Protected networks 
202 We examined all the PAs covered by the Central Corridor of the Brazilian Atlantic

203 Forest, providing information on the political categories and the sizes of each PA, as

204 well as their associated amphibian species richness and local environmental data. We

205 separated the PAs into two categories according to the IUCN criteria (IUCN 2018):

206 strict protection (IUCN categories I-II) and sustainable use (IUCN categories III-VI),

207 identifying the relative differences in the allocation of protection by each category. We

208 used national, state and municipal PAs spatial data through the Brazilian Ministry of the

209 Environment database (MMA 2015).

210 We assessed the relationships between species richness and their environmental

211 predictors (i.e., altitude, temperature, precipitation, and forest cover) to evaluate the

212 effect of environmental variables on the representation of species within the PAs

213 categories. For this, we performed a permutational multivariate analysis of variance

214 (PERMANOVA) using 1,000 permutations based on a Euclidean distance matrix,

215 through the "adonis" function in the R package "vegan" (Oksanen et al. 2013; R Core

216 Team 2016).

217

218 Species distribution data

219

220 We obtained spatial data of amphibian species through four steps: Firstly, we built a

221 dataset with all the species distributed in the Atlantic Forest according to Haddad et al.

222 (2013). Secondly, we included the species occurrences records available through the

223 Global Biodiversity Information Facility (GBIF: http://www.gbif.org). Thirdly, we

224 added spatial data for the mapping of species using the IUCN Red List of Threatened

225 Species database (IUCN 2018). Finally, we selected and filtered out the species that 
only occur in the forest remnants within the limits of distribution of the Central Corridor of the Brazilian Atlantic Forest, excluding all urban and non-forested areas (SOS Mata Atlântica and INPE 2015). Hence, we combined vector files based on expert knowledge of the species' ranges and forest remnant polygons into an overall coverage for species distribution modelling, through both sources of species presences (Fourcade 2016). We used ArcGIS 10 software (ESRI 2011) to build presence/absence matrices

232 from the species distribution data by overlapping a grid system with cells of 0.1

233 latitude/longitude degrees, creating a matrix with 838 grid cells. A total of 146 amphibian species were spatially represented in this grid system after using the "Spatial Join" tool available in ArcGIS. We only considered spatial occurrences by those species in which the distribution data intersected at least one grid cell (i.e., $\sim 10 \mathrm{~km}^{2}$ ). We used forest remnant data to meet the habitat patch requirements based on visual interpretation at a scale of 1:50,000, delimiting more than 260,000 forest remnants with a minimum mapping area of $0.3 \mathrm{~km}^{2}$. Therefore, we considered a species present in a cell if its spatial range intersected more than $0.3 \mathrm{~km}^{2}$. To improve coarse species distribution data, the "Count Overlapping Polygons" ArcGIS toolbox was used to obtain the species richness at the spatial resolution assessed, removing all duplicate records from the analyses (i.e., repeated records of a species at the same location).

\section{Climate models and environmental data}

247 Given that species occurrence patterns are determined at large-scales by responses of organisms to different climatic conditions (reflecting the ecological niche; see Soberón 2007; Booth et al. 2014), we used ecological niche models (ENMs) to predict the distribution area of amphibian species. We used the species occurrence matrix and the 
layers of climatic variables, resulting in a suitability matrix, which we used to model and map the potential distribution of each species evaluated (Loyola et al. 2014). Atmosphere-Ocean Global Climate Models (AOGCMs) to develop the spatial range models. These simulations show a high sensibility to detect potential impacts of land use changes on climate in human-induced landscapes (Dirmeyer et al. 2010). We implemented the Model for Interdisciplinary Research on Climate (MIROC5) by 2080 (mean of simulations for 2080-2100), which represents a moderated emission scenario within an optimistic context (Representative Concentration Pathway - RCP 4.5; Taylor et al. 2012). This moderate scenario (RCP4.5) incorporates historical emissions pathways and land cover information to meet potential climate policies (Thomson et al. 2011). We based the model projections on seven independent climatic variables tested by stepwise multiple regression analyses, using a confidence interval of 95\%: 1) annual mean temperature, 2) temperature seasonality, 3) mean temperature of the warmest and 4) coldest quarters, 5) annual precipitation, and 6) precipitation of the driest and 7) wettest quarters. We obtained these climatic data through the EcoClimate database 268 (Lima-Ribeiro et al. 2015) and downscaled them from 0.5 to 0.1 latitude/longitude degrees for fitting our spatial scale. We also used altitude as an environmental filter to

270 predict the species richness from the dataset available at WorldClim Global Climate

271 Data (Hijmans et al. 2005). Given that temperature and humidity are the main climate

272 components that directly affect the biology of amphibians (Carey and Alexander 2003),

273 we compared these variables along altitudinal gradients to evaluate which

274 environmental features are the best predictors of amphibian richness. 

software (Phillips et al. 2006) to develop the potential distribution map for the forest remnants associated with all the climatic variables adopted in the future predictions by 2080 (i.e., mean of simulations for 2080-2100). We randomly partitioned presence and pseudo-absence data for each species into $75 \%$ of calibration (i.e., training) and $25 \%$ of evaluation (i.e., tests), repeating this process ten times by cross-validation to avoid over-

281 fitting biases in the least-suitable environmental conditions. We converted the continuous predictions of suitability into a binary vector of $1 / 0$, finding the threshold that maximizes sensitivity and specificity values in the receiver-operating characteristic curves (Phillips et al. 2017) to build each ecological niche model. These curves are generated by plotting values of the relative frequency of true positive records predicted by a given model against the values of the relative frequency of pseudo-absence records, generating the Area Under the Curve (AUC). For this purpose, one-third of the occurrence records are set aside from modelling as test points (Phillips et al. 2006). Values of AUC range from 0.5 (i.e., random) for models with no predictive ability to

2901.0 for models giving perfect predictions. According to the Swets (1988) classification,

291 AUC values above 0.9 describe "very good", 0.8 "good", and 0.7 "useful" discrimination abilities.

The main reason behind our choice of the MaxEnt modelling approach was to look for a straightforward combination of environmental predictors that best explains the presence-only species distribution across forest remnants. Using presence-only data,

296 MaxEnt is considered one of the most efficient methods for habitat suitability modelling 297 in terms of predictive performance (Elith and Graham 2009; Phillips et al. 2017; Duflot 298 et al. 2018). This predictive modelling approach has a high analytical power to combine continuous and categorical environmental variables (Phillips et al. 2006), accounting for 
300 potential interactions among them (Phillips and Dudik 2008). MaxEnt also has been

301 considered as less sensitive to sample sizes and layer resolutions when compared with

302 other habitat suitability models (Merow and Silander 2014; Wisz et al. 2008). In

303 addition, this multi-attribute approach works in free, user-friendly software that

304 provides input and output files totally compatible with geographic information system

305 tools (Phillips et al. 2006).

306 We assessed the potential current and future distributions of the forest cover

307 according to the current vegetation remnants map of the Brazilian Atlantic Forest (SOS

308 Mata Atlântica and INPE 2015), of which we excluded all the areas where there are

309 currently agriculture, urban zones or settlements, only representing forest remnants

310 without overlaps on the land use/cover changes.

311

\section{Species turnover}

313

314 We also applied the maximum entropy method implemented in the MaxEnt software

315 (Phillips et al. 2006), to determine the species geographic distributions patterns,

316 following the same climatic variables adopted in the modelling process for the forest

317 remnants assessed. However, in this case, we employed the modelling strategy at the

318 community level of "predict first, assemble later" (Overton et al. 2002), where the

319 ranges of individual species are modelled one at a time as a function of environmental

320 predictors and then overlapped for obtaining the species richness. We calculated the

321 species turnover between current and future amphibian species distributions according

322 to the equation proposed by Thuiller et al. (2005) (1):

323

324

$$
\text { Species Turnover }=100 *((G+L) /(S+G))
$$


326 where " $G$ " refers to the number of species gained, " $L$ " the number of species lost and

327 " $S$ " the contemporary species richness found in the forest remnants assessed. We

328 obtained the final maps of species richness for the current and future times, as well as

329 the species turnover rates through the average of values projected by the MaxEnt model

330 for each grid cell assessed (i.e., 0.1 latitude/longitude degrees of spatial resolution).

331

332 Probability of connectivity

333

334 We assessed the forest remnants through the probability of connectivity (PC) index

335 (Saura and Rubio 2010), calculated for the patches of the Central Corridor of the

336 Brazilian Atlantic Forest under two environmental scenarios (i.e., current and future),

337 using Conefor 2.6 software (Saura and Torné 2009). The PC is a graph-based habitat

338 availability metric that quantifies functional connectivity (Saura and Rubio 2010). It is

339 defined as the probability that two points randomly placed within the landscape fall into

340 habitat areas that are reachable from each other (interconnected) given a set of " $n$ "

341 habitat patches and the links (direct connections) among them (Saura and Pascual-

342 Hortal 2007) (2).

$$
P C=\left(\sum_{i=0}^{n} \sum_{i=0}^{n} a_{1} x a_{j} x p_{i j}^{*}\right) / A_{L^{2}}=P C n u m / A_{L^{2}}
$$

where $a i$ and $a j$ are the attributes of patches $i$ and $j$ (i.e., ID and area). AL is the maximum landscape attribute, which corresponds to the total landscape area (i.e., area

348 of the study region, comprising both habitat and non-habitat patches). The product

349 probability of a path is the product of all the values of the probability of direct dispersal 
350 (Pij) for all the links in that path. Thus, $P i j$ is the maximum product probability of all of

351 the possible paths between patches $i$ and $j$, including direct dispersal between the two 352 patches.

353 We performed a prioritization ranking of the landscape elements (i.e., patches)

354 by their contribution to overall habitat availability and connectivity from the percentage

355 of the variation in $\mathrm{PC}\left(\mathrm{dPC}_{\mathrm{k}}\right)$, achieved by the removal of each patch from the overall 356 landscape (see Saura and Pascual-Hortal 2007; Saura and Rubio 2010). The $\mathrm{dPC}_{\mathrm{k}}$ is a

357 relative measure of the increase in the PC value that resulted from the improvement in

358 the strength of that link after the implementation of the defragmentation measures

359 (Saura and Rubio 2010) (3).

360

361

$$
d P C_{k}=100 \times\left(P C-P C_{\text {remove.k }}\right) / P C=100 \times\left(d P C_{k} / P C\right)
$$

362

363 where $\mathrm{PC}_{\text {remove.k }}$ is the index value after removal of the landscape element (i.e., after a

364 certain habitat patch loss). This measure corresponds to the "link change" analysis mode

365 implemented in the Conefor 2.6 software (Saura and Torné 2009). For all the

366 connectivity analyses, we used a mean dispersal distance for amphibians according to

367 the review conducted by Smith and Green (2005), where an estimative average distance

368 of $400 \mathrm{~m}$ for amphibians, in general, was proposed. Whereas some amphibians can

369 disperse over distances greater than $400 \mathrm{~m}$ (Smith and Green 2005), we also assessed

370 scenarios with a greater potential for dispersal, using distances of 600 and $800 \mathrm{~m}$. To

371 assess the ecological connectivity results for the future scenario, we considered only the

372 areas with an assessed likelihood greater than 50\%, considering the potential

373 distribution areas with a minimum favourable condition for the forest persistence under

374 the climate change predictions used. 


\section{Landscape resistance models}

377

378 We performed a landscape resistance approach to calculate the functional connectivity 379 between the forest remnants expressed as least-cost paths. To compare the sensitivity of 380 dPC models within the landscape, we used a resistance surface based on the landscape 381 heterogeneity with isolation-by-resistance (IBR), following the model proposed by 382 McRae (2006). We also assessed null models through isolation by Euclidean distance 383 (IBD), and isolation by Euclidean 3D distance with elevation data (IB3D), both of which 384 did not consider the influence of landscape heterogeneity. IBD and IB3D represent 385 landscape-free models and consider a maximum conductance for different land use types, 386 while IBR is strongly based on landscape heterogeneity. We estimated the resistance 387 values on the potential amphibian dispersal across the land use types within the landscape 388 matrix, according to a systematic mapping of land use at a 1:250,000 scale, provided by 389 the Brazilian Institute of Geography and Statistics (IBGE 2014).

390 We considered a conceptual framework for scoring the matrix permeability (cost

391 surface) associated with landscape features based on empirical data and expert opinion 392 (e.g., Ray et al. 2002; Joly et al. 2003; Semlitsch et al. 2008; Janin et al. 2009; Popescu

393 and Hunter 2011) to determine the resistance values assigned to each land use type.

394 Thus, we followed a rank-based criterion to reflect the relative order of landscape

395 conductance for amphibian ecological connectivity (e.g., Gibbs et al. 2005; Grant 2005;

396 Patrick 2006; Semlitsch et al. 2008; Popescu and Hunter 2011; Decout et al. 2012). We

397 used 27 detailed land use classes to generate our land cover input file, assuming

398 different resistance values to each land use type (Table S1). We estimated null

399 conductance values to each land use type for evaluating the extent to which the results 
were influenced by the magnitude of these values, where a low conductance value

401 indicates a high resistance to dispersal. Considering the current landscape heterogeneity,

402 we examined the relationship between landscape resistance distances (IBD, IB3D and

403 IBR) and ecological connectivity under present and future climate conditions (dPC

404 present and dPC future). For this, we used Mantel tests to account for statistical

405 significance in pairwise comparisons. We performed the Mantel tests through 200,000

406 permutations in the PASSaGE 2 software (Rosenberg and Anderson 2011). We used

407 Circuitscape 2.2 software (McRae 2006) to generate the pairwise matrices of landscape

408 resistance and to produce the cumulative land conductance maps based on circuit

409 theory.

410

411 Spatial prioritization framework

412

413 Finally, we selected the most suitable habitats defining different representation targets

414 based on four methodological steps (i.e. forest modelling, species modelling, probability

415 of connectivity and landscape resistance models) (Fig. 1). Combining these targets into

416 a landscape modelling approach, we designed a spatial representation to select priority

417 areas for conservation, which might work as a suitability surface for ecological

418 connectivity in the Central Corridor of the Brazilian Atlantic Forest. Therefore, this

419 approach favoured the selection of habitats less disturbed by human-induced actions for

420 improved conservation outcomes.

421

422 Results

423 
424 We showed that 110 PAs are covered by the Central Corridor of the Brazilian Atlantic

425 Forest (i.e. $70 \%$ of sustainable use and $30 \%$ of strict protection), which comprise to

$4266,607.98 \mathrm{~km}^{2}$ and correspond to only $8 \%$ of the total corridor area (Fig. 2a).

427 Considering the 146 amphibian species distributed in the forest remnants assessed (Fig.

428 2b), only $20 \%$ are distributed within the current PAs network. According to the

429 PERMANOVA, when we compared species richness and PA categories with all the

430 environmental variables together, we found direct relations with precipitation,

431 temperature, evapotranspiration and forest cover (Table 1), where precipitation was the

432 variable most associated with the amphibian species richness in the Central Corridor of

433 the Brazilian Atlantic Forest. According to the stepwise multiple regression analyses,

434 there was no correlation among any of the climate variables $\left(R^{2}=0.26 ; F=92.57 ; P=\right.$

435 0.078). The potential distribution of the forest remnants for the future scenario showed

436 an average AUC value of 0.86 , which indicated a good predictive ability by the dataset

437 provided (Fig. 3a). The climate change models predicted a reduction of $75 \%$ in the

438 probability of occurrence of the Atlantic Forest remnants in the central region of the

439 Central Corridor. The northern and southern edges of the Central Corridor, as well as

440 high altitude areas, showed the higher probability of forest occurrence. On the species

441 distribution models under climate change, we predicted a high amphibian turnover rate,

442 given that more than $50 \%$ of the grid cells had species turnover ratios greater than 0.7

443 (Fig. 3b). However, these expected changes in species composition tend to be greater on

444 the northern edge than the southern edge of the Central Corridor.

445 Considering a dispersal distance of $400 \mathrm{~m}$, our analyses of connectivity showed

446 that the Central Corridor of the Brazilian Atlantic Forest does not guarantee good

447 connectivity among the fragments, with an average dPC value of 8.43 . When we

448 assessed the dispersal distances of 600 and $800 \mathrm{~m}$, the average dPC was the same than 
that observed with a $400 \mathrm{~m}$ distance. However, our results showed higher connectivity areas in the northeastern region of the Central Corridor of the Brazilian Atlantic Forest, mainly in the southern Bahia region (Fig. 4). We found that $95 \%$ of the values pointed out by the connectivity index were directed to the sustainable use areas, only of which $5 \%$ are classified as integral protection areas (Table S2)

For the current scenario, we only found 10 PAs with high connectivity (dPC > $60.0)$, although 71 had very low values ( $\mathrm{dPC}<1.0)$. This situation can be aggravated considering the climate model results for the future (2080-2100), which showed a high probability of forest remnants retraction in the evaluated region. This represents $74 \%$ of connectivity loss in a total of 4,889.90 $\mathrm{km}^{2}$ of Atlantic Forest areas (Fig. 4). According to these future predictions, we estimated that 83 PAs would be without any ecological 460 connectivity by the years $2080-2100(\mathrm{dPC}<0.0)$, while only six PAs will remain with dPC higher than 1.0, which correspond to a plausible conservation attribute in terms of interpatch connectivity and habitat suitability. RPPN Renascer, RPPN Refúgio do Guigó I and II, and RPPN Boa União, in the Bahia state, and RPPN Mata da Serra, APA Serra da Vargem Alegre, and Parque Estadual do Forno Grande, in the Espírito Santo state represented the PAs with a better expected connectivity under climate change. Circuit theory current flow maps predicted a high likelihood of connectivity in

467 the central portion of our study area (i.e., in southern Bahia) for the current scenario 468 (Fig. 5). The landscape surface was represented by a general pattern of low-conductance 469 areas (i.e., low potential for amphibian dispersal), yet with some well-connected areas 470 showing low resistance for species moving between patches. These well-connected 471 areas (i.e., with high-conductance) can be potential amphibian biodiversity corridors, 472 which would connect the Monte Pascoal, Pau Brasil and Serra das Lontras PAs, located 473 in the southern Bahia region. Landscape resistance models that incorporated absolute 
474 dispersal barriers resulted in significant correlations when compared with those based

475 on landscape-free models (i.e., null resistances). The Mantel tests showed significantly

476 different relationships between dPC values (present and future) and resistance distances

477 (IBD, IB3D and IBR) (Table 2), indicating the sensitivity of the functional connectivity

478 models within the landscape.

479

480 Discussion

481

482 Habitat suitability assessment

483

484 Considering the effectiveness of habitat suitability models of our landscape planning,

485 we highlight the southern Bahia region and the Espírito Santo state with the best

486 ecological distances between forest remnants (i.e., high-conductance areas with low

487 resistance values). The use of resistance surfaces in landscape ecology incorporate

488 multiple pathways that rely on the habitat quality for identifying important landscape

489 elements connecting suitable environments for conservation (McRae et al. 2008; Zeller

490 et al. 2012). Interactions between habitat suitability and species dispersal movements

491 can be crucial for functional connectivity strategies in landscape change (Hodgson et al.

492 2009; Doerr et al. 2011). Therefore, given the landscape resistance surface and the

493 connectivity metrics used as an aid for our amphibian conservation approach, we

494 suggest some potential ecological corridors under current and future conditions.

495 Based on shifts in geographic ranges and climatically suitable habitats, our

496 results reveal that the areas with high turnover rates are not the same areas with high

497 occurrence probability of forest remnants under climate change. The selection of critical

498 habitats for amphibian conservation under climate change is important for making 
effective management decisions (Guisan et al. 2013). Forecasting approaches in spatial

500 planning suggest that regions with high species turnover rates are expected to have more

501 restricted-range species than regions with low species turnover rates (Diniz-Filho et al.

502 2009). Areas with high turnover rates can be associated to areas with low species

503 richness under the current climate (Duan et al. 2016), which in the case of the Atlantic

504 Forest may be represented by higher altitude areas. Moreover, low turnover rates in high

505 altitude areas can strengthen mountainous regions as potential climatic refuges

506 (Carnaval et al. 2009; Randin et al. 2009; Araújo et al. 2011; Lourenço-de-Moraes et al. 507 2019).

508 The use of MaxEnt as a single modelling algorithm for ecological approaches

509 also has some concerns regarding data acquisition and analysis, which should include

510 the full environmental range of the species (Elith et al. 2011). One of the main

511 limitations of this presence-only modelling seems to be a biased approach for species-

512 habitat relationships, given the unknown sampling effort intensity (Elith et al. 2011).

513 Addressing possible sampling limitations by combining local field records with

514 environmental layers is a promising strategy to improve the relevancy of habitat

515 suitability models for effective landscape planning (Maréchaux et al. 2017). Possible

516 solutions to avoid this sample selection bias can be corrected by adding a mask as an

517 explanatory variable or by discarding some of the presence points in oversampled areas

518 (Phillips et al. 2009; Radosavljevic and Anderson 2014; Stevenson-Holt et al. 2014).

519 Another limitation of our habitat suitability models is that climate datasets needed for

520 this modelling approach are not always available, and some of them need to be

521 downscaled for fitting our spatial scale (see Lima-Ribeiro et al. 2015). Therefore, we

522 assume that our climatic projections capture only part of the climate variability changes

523 associated with the habitat suitability models. However, downscaling climate 
524 projections is a widely used technique for exploring the regional and local-scale

525 responses to global climate change for simulating low-resolution climate models

526 (Hewitson and Crane 2006; Cabral et al. 2016). Given the on-going challenges to the

527 future development of climate downscaling, data scarcity and scale issues need to

528 diminish the overestimation of suitable habitats for future species distributions by

529 better-capturing landscape heterogeneity (Tabor and Williams 2010).

530

531 Challenges and opportunities for the Central Corridor of the Brazilian Atlantic

\section{Forest}

533

534 Our findings show that the proportion of forest fragments with good connectivity is very

535 low along the Central Corridor of the Brazilian Atlantic Forest, which consequently may reduce the flow of species among the fragments and significantly restricts the functional role of this ecological corridor. Using expert knowledge to distinguish species records can be a practical way of improving conservation-relevant decisions even with a paucity of biodiversity data (Akçakaya et al. 2018). We focus on an approach for allowing decision-makers to make the best use of the available data at a local scale, considering the extent to which such decisions might affect conservation outcomes at broad scales. The complementary use of species range maps with

543 occurrence data is a promising route for advancing efforts to local-scale conservation

544 decisions, supporting our species distribution data (Maréchaux et al. 2017). Such

545 approaches for improving decision-making effectiveness are even more urgent in 546 species-rich regions, where conservation strategies should ensure the lack of

547 biodiversity data (Maréchaux et al. 2017; Lourenço-de-Moraes et al. 2019). In this 548 context, we suggest that the forest fragments located in the coastal parts of the southern 
549 Bahia region and the Espírito Santo state deserve special attention in conservation plans

550 because they hold the highest proportion of ecological connectivity along the Central

551 Corridor of the Brazilian Atlantic Forest.

552 Our proposal of special attention to southern Bahia is reinforced due to their

553 resistance surface values within a landscape matrix composed by shaded cocoa

554 plantations (i.e., "cabrucas”), as indicated by Pardini et al. (2009). This agroforestry

555 system has allowed the conservation of large numbers of native plant species, besides

556 hosting typical mature forest fauna species (Pardini et al. 2009). Many amphibian

557 species use the bromeliads that are in the "cabrucas" system during their entire life cycle

558 and others only as diurnal shelter (Ferreira et al. 2016). Given their forest-like structure,

559 shaded cocoa plantations of the Forest remnants from southern Bahia perform a

560 fundamental role in maintaining connectivity between forest fragments (Sperber et al.

561 2004; Delabie et al. 2007; Faria and Baumgarten 2007). Our results, integrating graph-

562 based connectivity metrics into forecast models, indicate that this region has a high

563 probability of forest occurrence in a climate change scenario, which suggests

564 climatically suitable habitats and potential ecological corridors.

565 Forest remnants management is critical to ensure the persistence of species, but

566 dynamic threats such as land use change and climate change can directly reduce the

567 effectiveness of PAs planned under a static approach (Faleiro et al. 2013). Due to

568 developing technologies in remote sensing, there are several approaches to improve how

569 we assess and monitor forest remnants through a variety of spatial and temporal scales

570 (Tehrany et al. 2017). In this context, there is an urgent need to incorporate species

571 range shifts in spatial conservation plans to ensure their effectiveness in the future

572 (Hannah 2010). We recommend that the design of new conservation plans in the Central

573 Corridor of the Brazilian Atlantic Forest must attempt to re-establish ecological 
574 connectivity between the remaining fragments and the higher altitude areas. This

575 recommendation may represent an alternative mechanism to mitigate potential impacts

576 related to climate change and land use change in the Atlantic Forest Hotspot.

577 Corroborating our findings, other amphibian studies in the Atlantic Forest have also

578 warned about the need to invest in PAs near high altitude areas (Lemes and Loyola

579 2013; Loyola et al. 2014; Lourenço-de-Moraes et al. 2019), mainly in the southern

580 Bahia region (Carnaval et al. 2009), which retain high humidity provided by well-

581 preserved forest cover. Climate threats to amphibian biodiversity have often been

582 related to their high humidity dependence (Hopkins 2007), where moisture conditions

583 are associated with microhabitats, rainfall regimes and terrestrial water balance, limiting

584 the species' dispersal abilities (Early and Sax 2011). Dispersal limitation is a critical

585 determinant of amphibian geographical ranges, assuming a general metapopulation

586 structure related to habitat patch isolation (Smith and Green 2005). Our predictions on

587 the environmental variables for amphibian species richness in the Atlantic Forest are

588 dependent on their limited dispersal patterns. Therefore, dispersal capability might

589 severely limit the ability of species to track suitable climatic conditions geographically

590 (Massot et al. 2008; Early and Sax 2011). The use of various environmental variables

591 has been demonstrated as an efficient strategy to reach outcomes closer to reality, being

592 one of the keys to understanding how communities can respond to climatic factors

593 (Araújo and New 2007; Marmion et al. 2009).

595 Implications for conservation planning under climate change

597 Our findings show that potential impacts of climatic changes should occur in almost the 598 entire Central Corridor of the Brazilian Atlantic Forest, which could affect the 
ecological connectivity of the whole biome. We suggest that the PAs with the betterexpected connectivity under climate change need critical attention in future conservation plans (e.g., RPPN Renascer, RPPN Refúgio do Guigó I and II, and RPPN

602 Boa União, in the Bahia state, and RPPN Mata da Serra, APA Serra da Vargem Alegre, 603 and Parque Estadual do Forno Grande, in the Espírito Santo state). In this context, these 604 mitigations can be useful to avoid potential extinction process expected for the amphibians from the Central Corridor of the Brazilian Atlantic Forest PAs. Amphibian species from Atlantic Forest PAs are more threatened with

607 extinction than in other Brazilian protected networks (Campos et al. 2016). This

608 phenomenon happens mainly because the Southeast Region of Brazil is the economic

609 core of the country, with highly fragmented forest remnants (Ribeiro et al. 2009), with a

610 high human population density, and the presence of mining and logging activities

611 (Lemes et al. 2014). Atlantic Forest reserves close to urban ecosystems are also failing

612 to protect amphibian species (Lourenço-de-Moraes et al. 2018). Our approach does not

613 specifically estimate a quantitative species extinction risk but shows evidence of a

614 potential regional extinction within limited dispersal models. We highlight that many

615 PAs will become less effective in future scenarios, which can dramatically affect the

616 diversity and distribution of the amphibian species that occur in the forest remnants

617 assessed.

Conserving biodiversity under climate change comes out as a challenge for

619 conservation scientists. For being a dynamic system, controlling all the climatic

620 variables and synergies related to environmental conditions and its consequences is a

621 huge task. If the rates of climate change overtake the response potential of biological

622 systems to ecological connectivity and its impacts on ecosystem functioning, effects on

623 community structure and species distributions can be irreversible. Therefore, enhanced 
624 conservation efforts of forest management will play a critical role for mitigating effects

625 of environmental change. In some human-modified landscapes characterized by

626 secondary forest, environmental heterogeneity can be maintained and even increased,

627 thus contributing to the community structure (Tscharntke et al. 2012). A recent meta-

628 analysis showed that ecological restoration success can be higher for natural

629 regeneration than for active restoration in tropical forests (Crouzeilles et al. 2017). In

630 this context, our research highlights the importance of maintaining the mosaic of forest

631 remnants and the landscape heterogeneity in the Central Corridor of the Brazilian

632 Atlantic Forest, providing dynamic tools to prioritize conservation investment for

633 ecological connectivity assessments.

634 Practical strategies should be sensible for species adaptation, impact mitigation,

635 and must prioritize the protection and connectivity of heterogeneous landscapes to

636 improve conservation management (Richardson and Whittaker 2010). In the particular

637 case of the Atlantic Forest, the response of amphibians to anticipated declines depends

638 on local climatic conditions (Lourenço-de-Moraes et al. 2019). Regarding adaptation to

639 climate change, we show that species tend to use potential corridors in high altitude

640 areas with better-preserved forest cover. Our research highlights that integrating the

641 amphibian-climate refuges in the well-connected areas is essential for spatial decision-

642 making in the Atlantic Forest hotspot, which can reduce extinction risk and avoid

643 species loss. This work has advanced knowledge of the analytical methods that can be

644 used to incorporate landscape paths with low resistance into potentially connected areas

645 for amphibian conservation in the Central Corridor of the Brazilian Atlantic Forest. The

646 methodological approach proposed here is not only amphibian-specific but can also be

647 used in conservation plans for other taxonomic groups. This innovative approach has 
648 sought to move forward the knowledge on ecological connectivity of endangered forest

649 remnants and supports conservation actions in the face of climate change.

650

\section{Acknowledgements}

652

653 This work was supported by the CAPES Foundation, Ministry of Education of Brazil

654 (99999.001180/2013-04). We thank J. David and M. Rodrigues for useful comments on 655 the manuscript. We also thank the Center for Computational Biology and

656 Biotechnology Information Management (NBCGIB/UESC) and N. Sillero from CICGE

657 for making the use of supercomputers available. R.L.M. thanks funding from CNPq

$658 \quad(140710 / 2013-2 ; 152303 / 2016-2 ; 430195 / 2018-4)$.

659

660 Appendix A. Supplementary files

661

662 Supplementary files associated with this article can be found in the online version

663 (Tables S1 to S2).

664

665 References

666

667 Akçakaya HR, Bennett EL, Brooks TM, Grace MK, Heath A, Hedges S, Hilton-Taylor

668 C, Hoffmann D, Keith DA, Long B, Mallon DP, Meijaard E, Milner-Gulland EJ,

669 Rodrigues ASL, Rodriguez JP, Stephenson PJ, Stuart SN, Young RP (2018)

670 Quantifying species recovery and conservation success to develop an IUCN Green

671 List of Species. Conserv Biol 32:1128-1138. https://doi.org/10.1111/cobi.13112 
672 Araújo MB, Alagador D, Cabeza M, Nogués-Bravo D, Thuiller W (2011) Climate

673 change threatens European conservation areas. Ecol Lett 14:484-492.

674 https://doi.org/10.1111/j.1461-0248.2011.01610.x

675

Araújo MB, New M (2007) Ensemble forecasting of species distributions. Trends Ecol

676 Evol 22:42-47. https://doi.org/10.1016/j.tree.2006.09.010

677

Araújo MB, Peterson AT (2012) Uses and misuses of bioclimatic envelope modeling.

678 Ecology 93:1527-1539. https://doi.org/10.1890/11-1930.1

679

Austin JD, Lougheed SC, Neidrauer L, Chek AA, Boag PT (2002) Cryptic lineages in a 680

681

682 small frog: The post-glacial history of the spring peeper, Pseudacris crucifer (Anura: Hylidae). Mol Phylogenet Evol 25:316-329.

683 https://doi.org/10.1016/S1055-7903(02)00260-9

Austin MP, Van Niel KP (2011) Improving species distribution models for climate 684 change studies: Variable selection and scale. J Biogeogr 38:1-8.

685 https://doi.org/10.1111/j.1365-2699.2010.02416.x

Baum KA, Haynes KJ, Dillemuth FP, Cronin JT (2004) The matrix enhances the 687

688 effectiveness of corridors and stepping stones. Ecology 85:2671-2676. https://doi.org/10.1890/04-0500

689

Becker CG, Fonseca CR, Haddad CFB, Batista RF, Prado PI (2007) Habitat split and 690 the global decline of amphibians. Science 318:1775-1777.

692

693

Bennett G, Mulongoy KJ (2006). Review of experience with ecological networks, https://doi.org/10.1126/science.1149374

694 Bled F, Nichols JD, Altwegg R (2013) Dynamic occupancy models for analyzing 695 species' range dynamics across large geographic scales. Ecol Evol 3:4896-4909.

696 https://doi.org/10.1002/ece3.858 
697 Booth TH, Nix HA, Busby JR, Hutchinson MF (2014) Bioclim: the first species

698

699

700

701

702

703

704

705

706

707

708

709

710

711

712

713

714

715

716

717

718

719

720 distribution modelling package, its early applications and relevance to most current MaxEnt studies. Divers Distrib 20:1-9. https://doi.org/org/10.1111/ddi.12144.

Bridle JR, Vines TH (2007) Limits to evolution at range margins: when and why does adaptation fail? Trends Ecol Evol 22:140-147. https://doi.org/10.1016/j.tree.2006.11.002

Brown JH, Stevens GC, Kaufman DM (1996) The geographic range: Size, Shape, Boundaries, and Internal Structure. Annu Rev Ecol Evol Syst 27:597-623. https://doi.org/10.1146/annurev.ecolsys.27.1.597

Cabral P, Feger C, Levrel H, Chambolle M, Basque D (2016) Assessing the impact of land-cover changes on ecosystem services: a first step toward integrative planning in Bordeaux, France. Ecosyst Serv 22:318-327. https://doi.org/10.1016/j.ecoser.2016.08.005

Campos FS, Brito D, Solé M (2013) Threatened Amphibians and Their Conservation Status within the Protected Area Network in Northeastern Brazil. J Herpetol 47:277-285. https://doi.org/10.1670/11-158

Campos FS, Trindade-Filho J, Brito D, Llorente GA, Solé M (2014) The efficiency of indicator groups for the conservation of amphibians in the Brazilian Atlantic Forest. Ecol Evol 4:2505-2514. https://doi.org/10.1002/ece3.1073

Campos FS, Llorente GA, Rincón L, Lourenço-de-Moraes R, Solé M (2016) Protected areas network and conservation efforts concerning threatened amphibians in the Brazilian Atlantic Forest. Web Ecol 16:9-12. https://doi.org/10.5194/we-16-9- 
721 Campos FS, Lourenço-de-Moraes R, Llorente GA, Solé M (2017) Cost-effective conservation of amphibian ecology and evolution. Sci Adv 3:e1602929. https://doi.org/10.1126/sciadv.1602929

Carey C, Alexander MA (2003) Climate change and amphibian declines: is there a link? Divers Distrib 9:111-121. https://doi.org/10.1046/j.1472-4642.2003.00011.x

Carnaval AC, Hickerson MJ, Haddad CFB, Rodrigues MT, Moritz C (2009) Stability Predicts Genetic Diversity in the Brazilian Atlantic Forest Hotspot. Science 323:785-789. https://doi.org/10.1126/science.1166955

Carnaval AC, Moritz C (2008) Historical climate modelling predicts patterns of current biodiversity in the Brazilian Atlantic forest. J Biogeogr 35:1187-1201.

Carroll C, Noss RF, Paquet PC, Schumaker NH (2004) Extinction debt of protected areas in developing landscapes. Conserv Biol 18:1110-1120. https://doi.org/10.1111/j.1523-1739.2004.00083.x

Colwell RK, Brehm G, Cardelus CL, Gilman AC, Longino JT (2008) Global Warming, Elevational Range Shifts, and Lowland Biotic Attrition in the Wet Tropics.

Crouzeilles R, Ferreira MS, Chazdon RL, Lindenmayer DB, Sansevero JBB, Monteiro

Decout S, Manel S, Miaud C, Luque S (2012) Integrative approach for landscape-based graph connectivity analysis: A case study with the common frog (Rana temporaria) in human-dominated landscapes. Landsc Ecol 27:267-279. https://doi.org/10.1007/s10980-011-9694-z 
Delabie JHC, Jahyny B, Nascimento IC, Mariano CSF, Lacau S, Campiolo S, Philpott SM, Leponce M (2007) Contribution of cocoa plantations to the conservation of native ants (Insecta: Hymenoptera: Formicidae) with a special emphasis on the Atlantic Forest fauna of southern Bahia, Brazil. Biodivers Conserv 16:2359-2384. https://doi.org/10.1007/s10531-007-9190-6

Dias IR, Medeiros TT, Nova MFV, Solé M (2014) Amphibians of Serra Bonita, Southern bahia: A new hotpoint within Brazil's atlantic forest hotspot. ZooKeys 449:105-130. https://doi.org/10.3897/zookeys.449.7494

Dietz MS, Belote RT, Aplet GH, Aycrigg JL (2015) The world's largest wilderness protection network after 50years: An assessment of ecological system representation in the U.S. National Wilderness Preservation System. Biol Conserv 184: 431-438. https://doi.org/10.1016/j.biocon.2015.02.024

Diniz-Filho JAF, Bini LM, Rangel TF, Loyola RD, Hof C, Nogués-Bravo D, Araújo MB (2009) Partitioning and mapping uncertainties in ensembles of forecasts of species turnover under climate change. Ecography 32:897-906. https://doi.org/10.1111/j.1600-0587.2009.06196.x

Doerr VAJ, Barrett T, Doerr ED (2011) Connectivity, dispersal behaviour and conservation under climate change: A response to Hodgson et al. J Appl Ecol 48:143-147. https://doi.org/10.1111/j.1365-2664.2010.01899.x

Duan RY, Kong XQ, Huang MY, Varela S, Ji X (2016) The potential effects of climate change on amphibian distribution, range fragmentation and turnover in China. PeerJ 4:e2185. https://doi.org/10.7717/peerj.2185

Duflot R, Avon C, Roche P, Bergès L (2018) Combining habitat suitability models and spatial graphs for more effective landscape conservation planning: An applied 
methodological framework and a species case study. J Nat Conserv 46:38-47. https://doi.org/10.1016/j.jnc.2018.08.005

772

773

774

775

776

777

778

779

780

781

782

783

784

785

786

787

788

789

790

791

792

793

Dirmeyer PA, Niyogi D, de Noblet-Ducoudré N, Dickinson RE, Snyder PK (2010) Impacts of land use change on climate. Int J Climatol 30:1905-1907. https://doi.org/10.1002/joc.2157

Early R, Sax DF (2011) Analysis of climate paths reveals potential limitations on species range shifts. Ecol Lett 14:1125-1133. https://doi.org/10.1111/j.14610248.2011.01681.x

Elith J, Graham CH (2009) Do they? How do they? WHY do they differ? On finding reasons for differing performances of species distribution models. Ecography 32: 66-77. https://doi.org/10.1111/j.1600-0587.2008.05505.x

Elith J, Kearney M, Phillips S (2010) The art of modelling range-shifting species. Methods Ecol Evol 1:330-342. https://doi.org/10.1111/j.2041-210X.2010.00036.X

Elith J, Phillips SJ, Hastie T, Dudík M, Chee YE, Yates CJ (2011) A statistical explanation of MaxEnt for ecologists. Divers Distrib 17: 43-57. https://doi.org/10.1111/j.1472-4642.2010.00725.x

ESRI (2011) ArcGIS Desktop: Release 10. Environmental Systems Research Institute, Redlands

Faleiro FV, Machado RB, Loyola RD (2013) Defining spatial conservation priorities in the face of land-use and climate change. Biol Conserv 158: 248-257. https://doi.org/10.1016/j.biocon.2012.09.020

Faria D, Baumgarten J (2007) Shade cacao plantations (Theobroma cacao) and bat conservation in southern Bahia, Brazil. Biodivers Conserv 16:291-312. https://doi.org/10.1007/s10531-005-8346-5 
794 Faria D, Paciencia MLB, Dixo M, Laps RR, Baumgarten J (2007) Ferns, frogs, lizards, birds and bats in forest fragments and shade cacao plantations in two contrasting landscapes in the Atlantic forest, Brazil. Biodivers Conserv 16:2335-2357. https://doi.org/10.1007/s10531-007-9189-z

Ferreira RB, Lourenço-de-Moraes R, Teixeira RL, Beard KH (2016) Frogs associations with bromeliads in an abandoned cacao plantation in Northeastern Brazil. NorthWest J Zool 12:392-396

801 Fourcade Y (2016) Comparing species distributions modelled from occurrence data and

Franklin J (2010) Moving beyond static species distribution models in support of conservation biogeography. Divers Distrib 16:321-330. https://doi.org/10.1111/j.1472-4642.2010.00641.x

808 Frost DR (2019) Amphibian Species of the World: an Online Reference, Version 6.0.

809 American Museum of Natural History, New York.

810 http://research.amnh.org/herpetology/amphibia/index.html

811 Gaston KJ (2003) The Structure and Dynamics of Geographic Ranges. Oxford

$812 \quad$ University Press, Oxford

813 Gibbs JP, Whiteleather KK, Schueler FW (2005) Changes in frog and toad populations 814 over 30 years in New York State. Ecol App 15:1148-1157.

$815 \quad$ https://doi.org/10.1890/03-5408

816 Grant EHC (2005) Correlates of vernal pool occurrence in the Massachusetts, USA

817 landscape. Wetlands 25:480-487. https://doi.org/10.1672/22 
818 Guisan A, Tingley R, Baumgartner JB, Naujokaitis-Lewis I, Sutcliffe PR, Tulloch AI, Regan TJ, Brotons J, McDonald-Madden E, Mantyka-Pringle C, Martin TG, Rhodes JR, Maggini R, Setterfield SA, Elith J, Schwartz MW, Wintle BA, Broennimann O, Austin M, Ferrier S, Kearney MR, Possingham HP, Buckley

824 Gurrutxaga M, Rubio L, Saura S (2011) Key connectors in protected forest area networks and the impact of highways: A transnational case study from the Cantabrian Range to the Western Alps (SW Europe). Landsc Urban Plan 101:310-320. https://doi.org/10.1016/j.landurbplan.2011.02.036

Haddad CFB, Toledo LF, Prado CPA, Loebmann D, Gasparini JL, Sazima I (2013) Guia dos anfíbios da Mata Atlântica - diversidade e biologia. Anolis Books, São Paulo

Haddad NM, Brudvig LA, Clobert J, Davies KF, Gonzalez A, Holt RD, Lovejoy T, Sexton JO, Austin MP, Collins CD, Cook WM, Damschen EI, Ewers RM, Foster BL, Jenkins CN, King AJ, Laurance WF, Levey DJ, Margules CR, Melbourne BA, Nicholls AO, Orrock JL, Song D, Townshend JR (2015). Habitat fragmentation and its lasting impact on Earth's ecosystems. Sci Adv 1:e1500052. https://doi.org/10.1126/sciadv.1500052

837 Hamilton CM, Baumann M, Pidgeon AM, Helmers DP, Thogmartin WE, Heglund PJ, 838 Radeloff VC (2016) Past and predicted future effects of housing growth on open 839 space conservation opportunity areas and habitat connectivity around National 840 Wildlife Refuges. Landsc Ecol 31: 2175-2186. https://doi.org/10.1007/s10980841 016-0392-8 
842 Hannah L (2010) A global conservation system for climate-change adaptation: Special section. Conserv Biol 24:70-77. https://doi.org/10.1111/j.15231739.2009.01405.x

Hewitson BC, Crane RG (2006) Consensus between GCM climate change projections with empirical downscaling: precipitation downscaling over South Africa. Int J Climatol 26:1315-1337. https://doi.org/10.1002/joc.1314

Hijmans RJ, Cameron SE, Parra JL, Jones PG, Jarvis A (2005) Very high resolution interpolated climate surfaces for global land areas. Int J Climatol 25:1965-1978. https://doi.org/10.1002/joc.1276

Hodgson JA, Thomas CD, Wintle BA, Moilanen A (2009) Climate change, connectivity

Holt RD, Keitt TH (2000) Alternative causes for range limits: a metapopulation perspective. Ecol Lett 3:41-47. https://doi.org/10.1046/j.1461-0248.2000.00116.x

Hopkins WA (2007) Amphibians as Models for Studying Environmental Change. ILAR J 48:270-277. https://doi.org/10.1093/ilar.48.3.270

IBGE (2014) Mapa de Cobertura e Uso da Terra do Brasil 2014. Instituto Brasileiro de Geografia e Estatística. https://ww2.ibge.gov.br/home/geociencias/recursosnaturais/usodaterra/default.sht $\mathrm{m}$

862 IUCN (2018) The IUCN Red List of Threatened Species, Version 2018-2. http://www.iucnredlist.org/

864 Janin A, Léna JP, Ray N, Delacourt C, Allemand P, Joly P (2009) Assessing landscape connectivity with calibrated cost-distance modelling: Predicting common toad 

distribution in a context of spreading agriculture. J Appl Ecol 46:833-841. https://doi.org/10.1111/j.1365-2664.2009.01665.x

868

869

870

871

872

873

874

875

876

877

878

879

880

881

882

883

884

885

886

887

888

889

Jenkins CN, Van Houtan KS, Pimm SL, Sexton JO (2015) US protected lands mismatch biodiversity priorities. Proc Natl Acad Sci USA 112:5081-5086. https://doi.org/10.1073/pnas.1418034112

Joly P, Morand C, Cohas A (2003) Habitat fragmentation and amphibian conservation: building a tool for assessing landscape matrix connectivity. C R Biol 326:132139. https://doi.org/10.1016/S1631-0691(03)00050-7

Kearney MR, Wintle BA, Porter WP (2010) Correlative and mechanistic models of species distribution provide congruent forecasts under climate change. Conserv Lett 3:203-213. https://doi.org/10.1111/j.1755-263X.2010.00097.x

Kirkpatrick M, Barton NH (1997) Evolution of a species' range. Am Nat 150:1-23. https://doi.org/10.1086/286054

Laurance WF, Sayer J, Cassman, KG (2014) Agricultural expansion and its impacts on tropical nature. Trends Ecol Evol 29:107-116. https://doi.org/10.1016/j.tree.2013.12.001

Lawler JJ, White D (2008) Assessing the mechanisms behind successful surrogates for biodiversity in conservation planning. Anim Conserv 11:270-280. https://doi.org/10.1111/j.1469-1795.2008.00176.x

Lee-Yaw JA, Davidson A, McRae BH, Green DM (2009) Do landscape processes predict phylogeographic patterns in the wood frog? Mol Ecol 18:1863-1874. https://doi.org/10.1111/j.1365-294X.2009.04152.x

Le Saout S, Hoffmann M, Shi Y, Hughes A, Bernard C, Brooks TM, Bertzky B, Butchart SHM, Stuart SN, Badman T, Rodrigues ASL (2013) Protected Areas and 

https://doi.org/10.1126/science.1239268

Lemes P, Loyola RD (2013) Accommodating Species Climate-Forced Dispersal and

$894 \quad$ Uncertainties in Spatial Conservation Planning. PLoS ONE 8:e54323.

895 https://doi.org/10.1371/journal.pone.0054323

896 Lemes P, Melo AS, Loyola RD (2014) Climate change threatens protected areas of the 897 Atlantic Forest. Biodivers Conserv 23:357-368. https://doi.org/10.1007/s10531013-0605-2

899 Liang J, He X, Zeng G, Zhong M, Gao X, Li X, Li X, Wu H, Feng C, Xing W, Fang Y, 900 Mo D (2018) Integrating priority areas and ecological corridors into national 901 network for conservation planning in China. Sci Total Environ 626:22-29. DOI: $10.1016 / \mathrm{j}$. scitotenv.2018.01.086

903

904

905

906

907

908

909

910

911

912

913

914

Lima-Ribeiro MS, Varela S, González-Hernández J, de Oliveira G, Diniz-Filho JAF, Terribile LC (2015) EcoClimate: a database of climate data from multiple models for past, present, and future for macroecologists and biogeographers. Biodivers Informatics, 10:1-21. https://doi.org/10.17161/bi.v10i0.4955

Lourenço-de-Moraes R, Malagoli LR, Guerra V, Ferreira RB, Affonso IP, Haddad CFB, Sawaya RJ, Bastos RP (2018) Nesting patterns among Neotropical species assemblages: can reserves in urban areas be failing to protect anurans? Urban Ecosyst 5:933-942. https://doi.org/10.1007/s11252-018-0767-5

Lourenço-de-Moraes R, Campos FC, Ferreira RB, Solé M, Beard KH, Bastos RP (2019) Back to the future: Conserving functional and phylogenetic diversity in amphibian 
915 Loyola RD, Becker CG, Kubota U, Haddad CFB, Fonseca CR, Lewinsohn TM (2008)

$916 \quad$ Hung out to dry: Choice of priority ecoregions for conserving threatened

917 neotropical anurans depends on life-history traits. PLoS ONE:e2120.

918 https://doi.org/10.1371/journal.pone.0002120

919 Loyola RD, Lemes P, Brum FT, Provete DB, Duarte LDS (2014) Clade-specific

920 consequences of climate change to amphibians in Atlantic Forest protected areas.

$921 \quad$ Ecography 37:65-72. https://doi.org/10.1111/j.1600-0587.2013.00396.x

922 Maréchaux I, Rodrigues ASL, Charpentier A (2017) The value of coarse species range

923 maps to inform local biodiversity conservation in a global context. Ecography

$924 \quad 40: 1166-1176$. https://doi.org/10.1111/ecog.02598

925 Marmion M, Parviainen M, Luoto M, Heikkinen RK, Thuiller W (2009) Evaluation of

926 consensus methods in predictive species distribution modelling. Divers Distrib

927

15:59-69. https://doi.org/10.1111/j.1472-4642.2008.00491.x

928

Martensen AC, Saura S, Fortin MJ (2017) Spatio-temporal connectivity: assessing the

929 amount of reachable habitat in dynamic landscapes. Methods Ecolo Evol 8:1253-

930 1264. https://doi.org/10.1111/2041-210X.12799

931 Massot M, Clobert J, Ferrière R (2008) Climate warming, dispersal inhibition and 932 extinction risk. Glob Chang Biol 14:461-469. https://doi.org/10.1111/j.1365-

933 2486.2007.01514.x

934 McRae BH (2006) Isolation by resistance. Evolution 60:1551-1561.

935 https://doi.org/10.1554/05-321.1

936 McRae BH, Dickson BG, Keitt TH, Shah VB (2008) Using circuit theory to model

937 connectivity in ecology, evolution, and conservation. Ecology 89:2712-2724.

938 https://doi.org/10.1890/07-1861.1 
Merow C, Silander Jr JA (2014) A comparison of Maxlike and Maxent for modelling species distributions. Methods Ecol Evol 5:215-225. https://doi.org/10.1111/2041-210X.12152

Metzger JP (2009) Conservation issues in the Brazilian Atlantic forest. Biol Conserv 142:1138-1140. https://doi.org/10.1016/j.biocon.2008.10.012

Mittermeier RA, Turner WR, Larsen FW, Brooks TM, Gascon C (2011) Global Biodiversity Conservation: The Critical Role of Hotspots. In: Zachos F, Habel J (eds) Biodiversity Hotspots, Springer, Berlin, pp 3-22. https://doi.org/10.1007/978-3-642-20992-5_1

MMA (2015) Cadastro Nacional de Unidades de Conservação. Brasil: Ministério do Meio Ambiente, Brasília. http://www.mma.gov.br/cadastro_uc/

Morais AR, Siqueira MN, Lemes P, Maciel NM, de Marco P, Brito D (2013) Unraveling the conservation status of data deficient species. Biol Conserv 166:98-102. http://dx.doi.org/10.1016/j.biocon.2013.06.010

Nori J, Lemes P, Urbina-Cardona N, Baldo D, Lescano J, Loyola R (2015) Amphibian conservation, land-use changes and protected areas: A global overview. Biol Conserv 191:367-374. https://doi.org/10.1016/j.biocon.2015.07.028

Ochoa-Ochoa L, Urbina-Cardona JN, Vázquez LB, Flores-Villela O, Bezaury-Creel J (2009) The effects of governmental protected areas and social initiatives for land protection on the conservation of Mexican amphibians. PLoS ONE 4:e6878. https://doi.org/10.1371/journal.pone.0006878

Oksanen J, Blanchet FG, Kindt R, Legendre P, Minchin P, O’Hara RB, Simpson GL, Solymos P, Stevens MHH, Szoecs E, Wagner H (2013) Vegan: Community Ecology Package. R Foundation for Statistical Computing, Vienna. https://doi.org/10.4135/9781412971874.n145 
964 Opdam P, Wascher D (2004) Climate change meets habitat fragmentation: Linking 965 landscape and biogeographical scale levels in research and conservation. Biol Conserv 117:285-297. https://doi.org/10.1016/j.biocon.2003.12.008

967 Overton JMC, Stephens RTT, Leathwick JR, Lehmann A (2002) Information pyramids 968 for informed biodiversity conservation. Biodivers Conserv 11:2093-2116.

969 https://doi.org/10.1023/A:1021386426790

970 Pardini R, Faria D, Accacio GM, Laps RR, Mariano-Neto E, Paciencia ML, Dixo M, 971 Baumgarten J (2009) The challenge of maintaining Atlantic forest biodiversity: A multi-taxa conservation assessment of specialist and generalist species in an agroforestry mosaic in southern Bahia. Biol Conserv 142:1178-1190.

974 https://doi.org/10.1016/j.biocon.2009.02.010

975 Patrick DA, Hunter ML, Calhoun AJK (2006) Effects of experimental forestry 976 treatments on a Maine amphibian community. Forest Ecol Manag 234:323-332. https://doi.org/10.1016/j.foreco.2006.07.015

Pearson RG, Dawson TP (2003) Predicting the impacts of climate change on the distribution of species: Are bioclimate envelope models useful? Glob Ecol Biogeogr 12:361-371. https://doi.org/10.1046/j.1466-822X.2003.00042.x

Pearson RG, Dawson TP (2005) Long-distance plant dispersal and habitat fragmentation: Identifying conservation targets for spatial landscape planning under climate change. Biol Conserv 123:389-401.

984 https://doi.org/10.1016/j.biocon.2004.12.006

985 Peterson T, Ortega-Huerta M, Bartley J, Sánchez-Cordero V, Soberón J, Buddemeier 986 RH, Stockwell DRB (2002) Future projections for Mexican faunas under global climate change scenarios. Nature 416:626-9. https://doi.org/10.1038/416626a 
Peterson AT, Soberón J, Pearson RG, Anderson RP, Martínez-Meyer E, Nakamura M, Araújo MB (2011) Ecological niches and geographical distributions. Princeton University Press, New Jersey

Phillips SJ, Anderson RP, Schapire RE (2006) Maximum entropy modeling of species geographic distributions. Ecol Modell 190:231-259. https://doi.org/10.1016/j.ecolmodel.2005.03.026

Phillips SJ, Dudík M (2008) Modeling of species distributions with Maxent: new extensions and a comprehensive evaluation. Ecography 31:161-175. https://doi.org/10.1111/j.0906-7590.2008.5203.x

Phillips SJ, Dudík M, Elith J, Graham CH, Lehmann A, Leathwick J, Ferrier, S (2009) Sample selection bias and presence-only distribution models: implications for background and pseudo-absence data. Ecol Appl 19:181-197. https://doi.org/10.1890/07-2153.1

Phillips SJ, Anderson RP, Dudík M, Schapire RE, Blair ME (2017) Opening the black box: an open-source release of Maxent. Ecography 40:887-893. https://doi.org/10.1111/ecog.03049

Popescu VD, Hunter ML (2011) Clear-cutting affects habitat connectivity for a forest amphibian by decreasing permeability to juvenile movements. Ecol Appl 21:1283-1295. https://doi.org/10.1890/10-0658.1

R Core Team (2016). R: A Language and Environment for Statistical Computing. R Foundation for Statistical Computing, Vienna. https://www.R-project.org/ Radosavljevic A, Anderson RP (2014) Making better Maxent models of species distributions: complexity, overfitting and evaluation. J Biogeogr 41:629-643. https://doi.org/10.1111/jbi.12227 
1012 Randin CF, Engler R, Normand S, Zappa M, Zimmermann NE, Pearman PB, Vittoz A,

1013 Thuiller W, Guisan A (2009) Climate change and plant distribution: Local models

1014 predict high-elevation persistence. Glob Chang Biol 15:1557-1569.

1015 https://doi.org/10.1111/j.1365-2486.2008.01766.x

1016 Rangel TF, Loyola RD (2012) Labeling ecological niche models. Nat Conserv 10:119-

$1017 \quad 126 \mathrm{https}: / / 10.4322 /$ natcon.2012.030

1018 Raxworthy CJ, Pearson RG, Rabibisoa N, Rakotondrazafy AM, Ramanamanjato JB,

1019 Raselimanana AP, Wu S, Nussbaum RA, Stone DA (2008) Extinction

1020 vulnerability of tropical montane endemism from warming and upslope

1021 displacement: A preliminary appraisal for the highest massif in Madagascar. Glob

$1022 \quad$ Chang Biol 14:1703-1720. https://doi.org/10.1111/j.1365-2486.2008.01596.x

1023 Ray N, Lehmann A, Joly P, (2002) Modeling spatial distribution of amphibian

1024 populations: A GIS approach based on habitat matrix permeability. Biodivers

1025 Conserv 11:2143-2165. https://doi.org/10.1023/A:1021390527698

1026 Ribeiro MC, Metzger JP, Martensen AC, Ponzoni FJ, Hirota MM (2009) The Brazilian

1027 Atlantic Forest: How much is left, and how is the remaining forest distributed?

1028

1029 Implications for conservation. Biol Conserv 142:1141-1153.

1030

Richardson DM, Whittaker RJ (2010) Conservation biogeography - foundations, concepts and challenges. Divers Dist 16:313-320. https://doi.org/10.1111/j.14724642.2010.00660.x

1034

Rodrigues ASL, Andelman SJ, Bakarr MI, Boitani L, Brooks TM, Cowling RM, Fishpool LDC, da Fonseca GAB, Gaston KJ, Hoffmann M, Long JS, Marquet PA, Pilgrim JD, Pressey RL, Schipper J, Sechrest W, Stuart SN, Underhill LG, Waller RW, Watts MEJ, Yan X (2004) Effectiveness of the global protected area network 
in representing species diversity. Nature 428:640-643. https://doi.org/10.1038/nature02422

Rosenberg DK, Noon BR, Meslow EC (1997) Biological Corridors: Form, Function, and Efficacy. BioScience 47:677-687. https://doi.org/10.2307/1313208

Rosenberg MS, Anderson CD (2011) PASSaGE: Pattern Analysis, Spatial Statistics and Geographic Exegesis, Version 2. Methods Ecol Evol 2:229-232. https://doi.org/10.1111/j.2041-210X.2010.00081.x

Saura S, Pascual-Hortal L (2007) A new habitat availability index to integrate connectivity in landscape conservation planning: Comparison with existing indices and application to a case study. Landsc Urban Plan 83:91-103.

Saura S, Torné J (2009) Conefor Sensinode 2.2: A software package for quantifying the importance of habitat patches for landscape connectivity. Environ Model Softw 24:135-139. https://doi.org/10.1016/j.envsoft.2008.05.005

Semlitsch RD, Conner CA, Hocking DJ, Rittenhouse TAG, Harper EB (2008) Effects

Smith MA, Green DM (2005) Dispersal and the metapopulation in amphibian and paradigm ecology are all amphibian conservation: populations metapopulations? 
1062 Soberón J (2007) Grinnellian and Eltonian niches and geographic distributions of $1063 \quad$ species. Ecol Lett 10: 1115-1123. https://doi.org/10.1111/j.1461-

$1064 \quad$ 0248.2007.01107.x

1065 SOS Mata Atlântica, INPE (2015) Atlas dos Remanescentes Florestais da Mata

1066 Atlântica Período 2013-2014. https://www.sosma.org.br/projeto/atlas-da-mata-

1067 atlantica/dados-mais-recentes/

1068 Spear SF, Peterson CR, Matocq MD, Storfer A (2005) Landscape genetics of the 1069 blotched tiger salamander (Ambystoma tigrinum melanostictum). Mol Ecol 14:2553-2564. https://doi.org/10.1111/j.1365-294X.2005.02573.x

1071 Spear SF, Balkenhol N, Fortin MJ, McRae BH, Scribner K (2010) Use of resistance 1072 surfaces for landscape genetic studies: Considerations for parameterization and analysis. Mol Ecol 19:3576-3591. https://doi.org/10.1111/j.1365-

1075

Sperber CF, Nakayama K, Valverde MJ, Neves FS (2004) Tree species richness and density affect parasitoid diversity in cacao agroforestry. Basic Appl Ecol 5:241-

Stebbins RC, Cohen, NW (1995) A natural history of amphibians. Princeton University 1079 Press, Princeton

Stevenson-Holt CD, Watts K, Bellamy CC, Nevin OT, Ramsey AD (2014) Defining landscape resistance values in least-cost connectivity models for the invasive grey RW (2004) Status and trends of amphibian declines and extinctions worldwide. Science 306:1783-1786. https://doi.org/10.1126/science.1103538 
1087 Swets JA (1988) Measuring the accuracy of diagnostic systems. Science 240: 1285-

1088

1089

1090

1091

1092

1093

1094

1095

1096

1097

1098

1099

1100

1101

1102

1103

1104

1105

1106

1107

1108

1109

1110 1293. https://doi.org/10.1126/science.3287615

Tabarelli M, Silva JMC, Gascon C (2004) Forest fragmentation, synergisms and the impoverishment of neotropical forests. Biodivers Conserv 13:1419-1425. https://doi.org/10.1023/B:BIOC.0000019398.36045.1b

Tabarelli M, Pinto LP, Silva JMC, Hirota M, Bede L (2005) Challenges and Opportunities for Biodiversity Conservation in the Brazilian Atlantic Forest. Conserv Biol 19:695-700. https://doi.org/10.1111/j.1523-1739.2005.00694.x

Tabor K, Williams JW (2010) Globally downscaled climate projections for assessing the conservation impacts of climate change. Ecol Appl 20:554-565. https://doi.org/10.1890/09-0173.1

Taylor KE, Stouffer RJ, Meehl GA (2012) An overview of CMIP5 and the experiment design. B Am Meteorol Soc 93:485-498. https://doi.org/10.1175/BAMS-D-1100094.1

Tehrany MS, Kumar L, Drielsma MJ (2017) Review of native vegetation condition assessment concepts, methods and future trends. J Nat Conserv 40:12-23. https://doi.org/10.1016/j.jnc.2017.08.004

Teixeira AMG, Soares-Filho BS, Freitas SR, Metzger JP (2009) Modeling landscape dynamics in an Atlantic Rainforest region: Implications for conservation. Forest Ecol Manag 257:1219-1230. https://doi.org/10.1016/j.foreco.2008.10.011

Thomson AM, Calvin KV, Smith SJ, Kyle GP, Volke A, Patel P, Delgado-Arias S, Bond-Lamberty B, Wise MA, Clarke LE, Edmonds JA (2011) RCP4. 5: a pathway for stabilization of radiative forcing by 2100 . Clim Change 109:77. https://doi.org/10.1007/s10584-011-0151-4 
1111 Thuiller W, Lavorel S, Araujo MB, Sykes MT, Prentice IC (2005) Climate change

1112 threats to plant diversity in Europe. Proc Natl Acad Sci USA 102:8245-8250.

$1113 \quad$ https://doi.org/10.1073/pnas.0409902102

1114 Tischendorf L, Fahrig L (2000) On the usage and measurement of landscape

1115 connectivity. Oikos 90:7-19. https://doi.org/10.1034/j.1600-0706.2000.900102.x

1116 Triviño M, Kujala H, Araújo MB, Cabeza M (2018) Planning for the future: identifying

1117 conservation priority areas for Iberian birds under climate change. Landsc Ecol

1118 33:659-673. https://doi.org/10.1007/s10980-018-0626-Z

1119 Tscharntke T, Tylianakis JM, Rand TA, Didham RK, Fahrig L, Batáry P, Bengtsson J,

1120 Clough Y, Crist TO, Dormann CF, Ewers RM, Fründ J, Holt RD, Holzschuh A,

1121 Klein AM, Kleijn D, Kremen C, Landis DA, Laurance W, Lindenmayer D,

1122 Scherber C, Sodhi N, Steffan-Dewenter I, Thies C, van der Putten WH,

1123 Westphal C (2012) Landscape moderation of biodiversity patterns and processes -

1124 eight hypotheses. Biol Rev 87:661-685. https://doi.org/10.1111/j.1469-

$1125 \quad$ 185X.2011.00216.X

1126 Urban D, Keitt T (2001). Landscape connectivity: A graph-theoretic perspective.

$1127 \quad$ Ecology 82:1205-1218. https://doi.org/10.1890/0012-

1128 9658(2001)082[1205:lcagtp]2.0.co;2

1129 Urbina-Cardona, JN (2008) Conservation of Neotropical Herpetofauna: Research

$1130 \quad$ Trends and Challenges. Trop Conserv Sci 11: 359-375.

$1131 \quad$ https://doi.org/10.1177/194008290800100405

1132 Verdade VK, Valdujo PH, Carnaval AC, Schiesari L, Toledo LF, Mott T, Andrade GV,

1133 Eterovick PC, Menin M, Pimenta BVS, Nogueira C, Lisboa CS, de Paula CD,

1134 Silvano (2012). A leap further: the Brazilian amphibian conservation action plan.

$1135 \quad$ Alytes 29:28-43. 
1136 Wisz MS, Hijmans RJ, Li J, Peterson AT, Graham CH, Guisan A, NCEAS Predicting

1137 Species Distributions Working Group (2008) Effects of sample size on the

$1138 \quad$ performance of species distribution models. Divers Dist 14:763-773.

1139 https://doi.org/10.1111/j.1472-4642.2008.00482.x

1140 Worboys GL, Francis WL, Lockwood M (2010) Connectivity Conservation

$1141 \quad$ Management: A Global Guide. Earthscan, London

1142 Young BE, Stuart SN, Chanson JS, Cox NA, Boucher TM (2004) Disappearing jewels:

1143 the status of New World amphibians. NatureServe, Virginia

1144 Zeller KA, McGarigal K, Whiteley AR (2012) Estimating landscape resistance to

1145 movement: a review. Landsc Ecol 27:777-797. https://doi.org/10.1007/s10980-

$1146 \quad \underline{012-9737-0}$

1147 
1150 Table 1. Results from the PERMANOVA on the species richness and PA categories by

1151 the variables altitude, temperature, precipitation and forest cover in the Central Corridor

1152 of the Brazilian Atlantic Forest.

\begin{tabular}{lcccc}
\hline Environmental Variables & df & $F$ & $R^{2}$ & $P$ value \\
& \multicolumn{5}{c}{ model } \\
\hline Altitude & 1 & 21.27 & 0.06 & 0.98 \\
Temperature & 1 & 43.70 & 0.14 & $0.00^{*}$ \\
Precipitation & 1 & 130.71 & 0.42 & $0.00^{*}$ \\
Forest cover & 1 & 27.88 & 0.09 & $0.02^{*}$ \\
Residuals & 105 & - & 0.29 & - \\
Total & 109 & - & 1.00 & - \\
\end{tabular}


1171 Table 2. Statistical significance for Mantel test between dPC values (Present and Future)

1172 and resistance distances (IBD, IB3D and IBR) for calculating the landscape connectivity

1173 between forest remnants in the in the Central Corridor of the Brazilian Atlantic Forest.

1174 IBD: null model through isolation by Euclidean distance; IB3D: null model through

1175 isolation by Euclidean 3D distance with elevation data; IBR: resistance model through

1176 isolation-by-resistance between patches based on landscape heterogeneity.

\begin{tabular}{lcc}
\hline Matrix & Mantel r & P-value \\
\hline dPC Present-IBD & 0.01091 & 0.00000 \\
dPC Present-IB3D & 0.01055 & 0.00000 \\
dPC Present-IBR & 0.00962 & 0.00000 \\
dPC Future-IBD & 0.00316 & 0.03253 \\
dPC Future-IB3D & 0.00295 & 0.04637 \\
dPC Future-IBR & 0.00310 & 0.03871 \\
\hline
\end{tabular}

1177 All tested pairs for dPC-Present and dPC-Future are significant $(\mathrm{p}>0.05)$.

1178

1179

1180

1181

1182 
$1195 \quad$ Figures

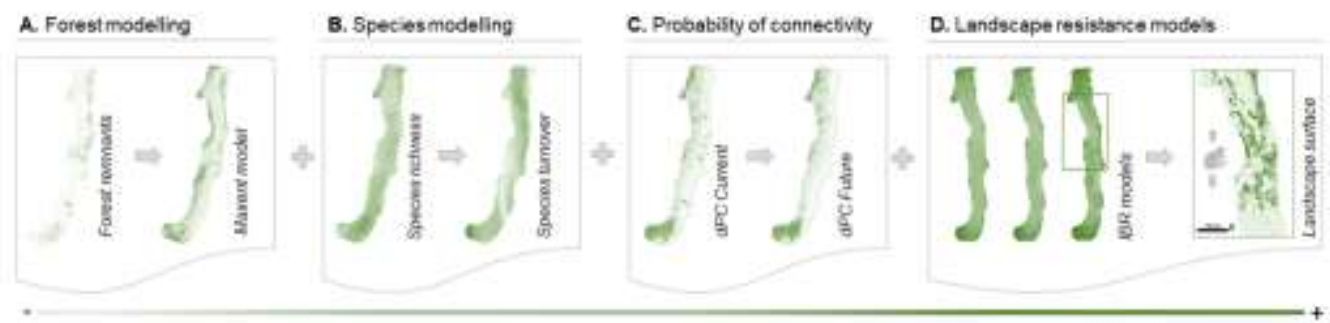

1196

1197 Fig. 1. Schematic representation of the methodological steps used in the landscape

1198 modelling approach for amphibian conservation in the Central Corridor of the Brazilian

1199 Atlantic Forest, Brazil. Forest modelling (A), Species modelling (B), Probability of

1200 connectivity (C) and Landscape resistance models (D). 

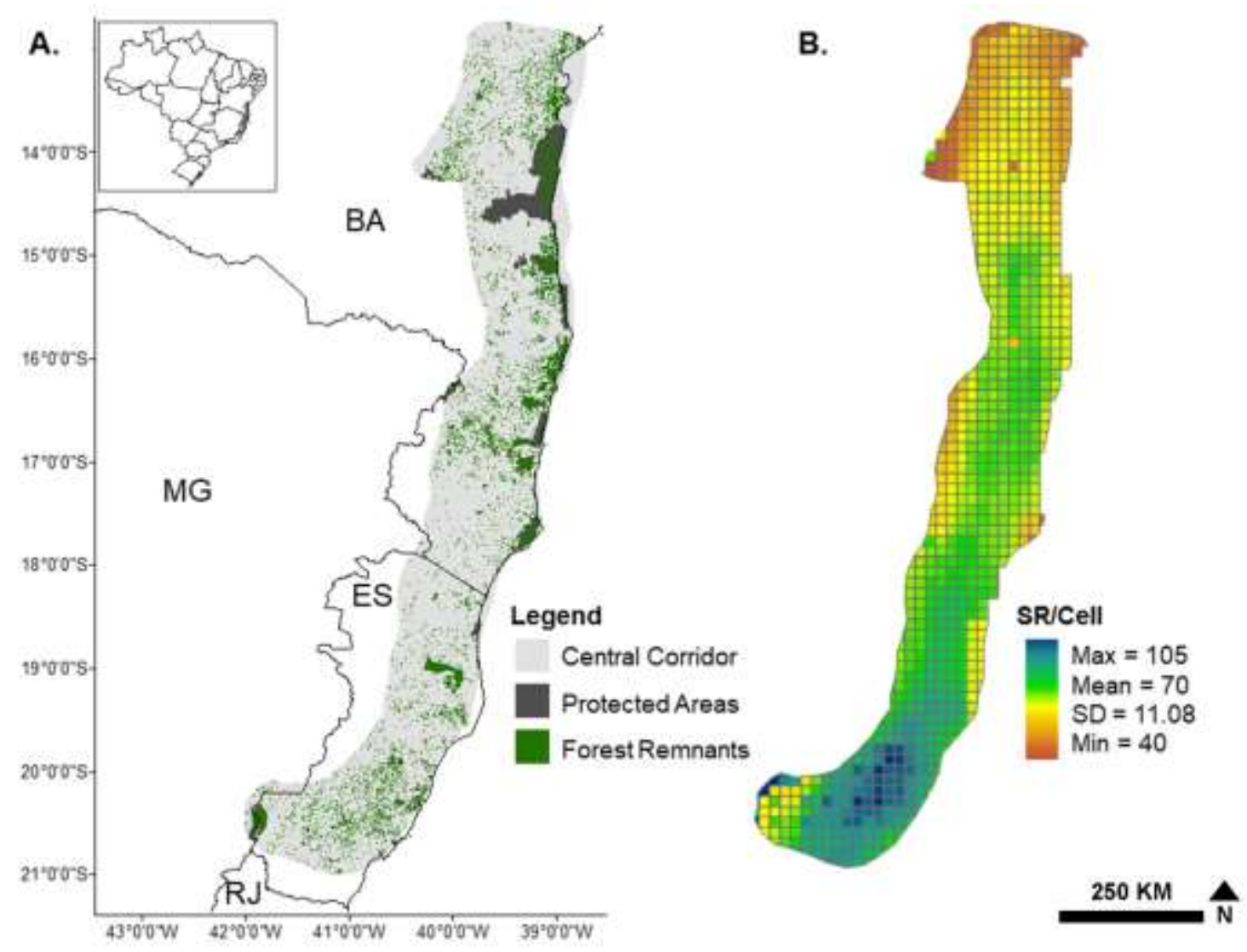

1203 Fig. 2. Location of the Central Corridor of the Brazilian Atlantic Forest, in eastern

1204 Brazil, representing their Protected Areas and Forest Remnants. BA: Bahia state; MG:

1205 Minas Gerais state; ES: Espírito Santo state; RJ: Rio de Janeiro state (A). Species

1206 Richness per grid cell with summary statistic values such as Maximum, Mean, Standard

1207 Deviation and Minimum (B).

1208 
A. Probability of forest occurrence

0.86

0.72

0.57

0.43

0.28

0.14

0.00
B. Amphibian species

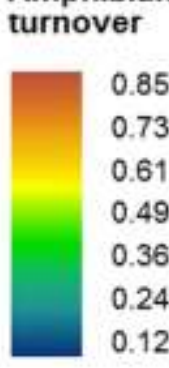

1210 Fig. 3. Probability of forest cover according to the MaxEnt model (A), and amphibian

1211 species turnover rate (B), under climate change in the Central Corridor of the Brazilian 1212 Atlantic Forest.

1213 

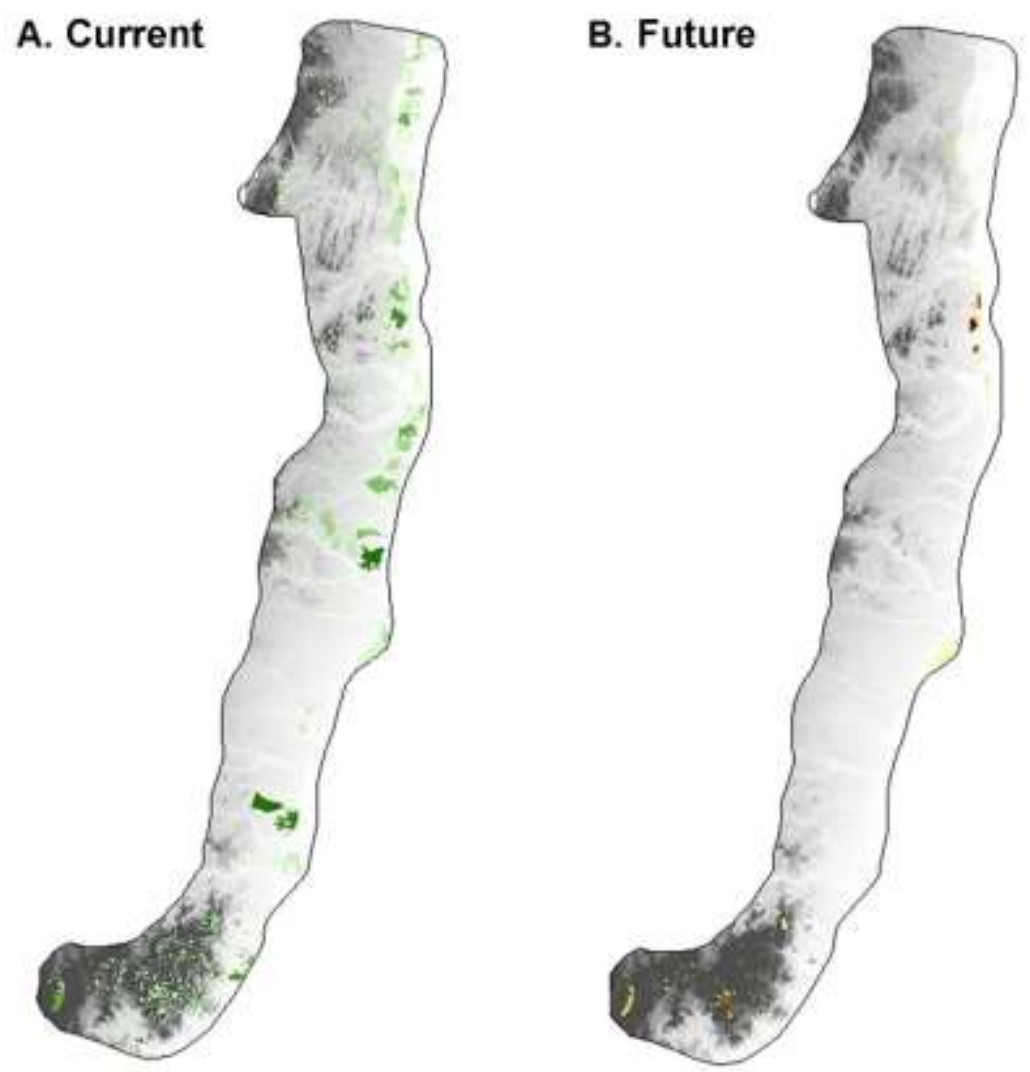

dPC Current

High: 60.30

Low: 0.00

dPC Future

High: 21.89

Low: 0.00

\section{Altitude (m)}

High: 2,585

Low: 0

1214

1215 Fig. 4. Potential amphibian ecological connectivity under dPC models for current (A),

1216 and future (B) scenarios, across the forest remnants in the Central Corridor of the

1217 Brazilian Atlantic Forest with altitudinal representation.

1218 
A.

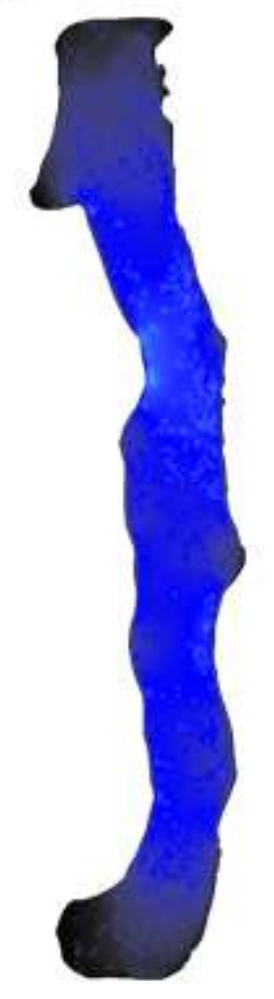

B.

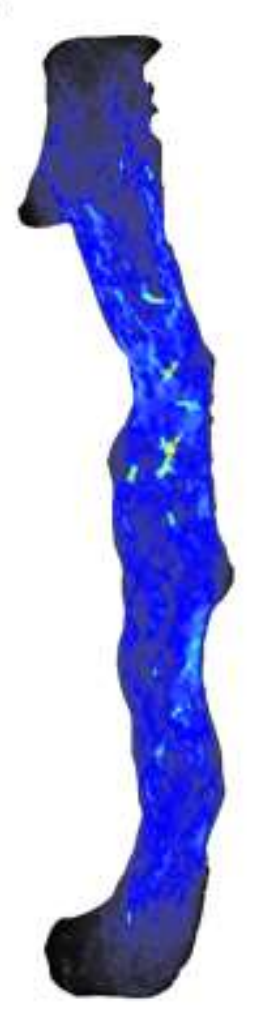

C.

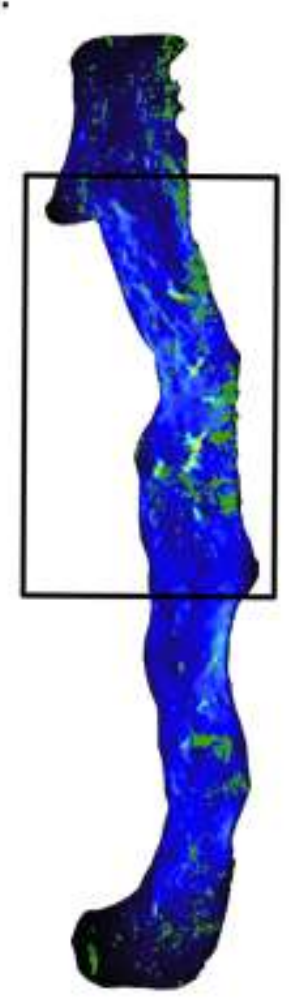

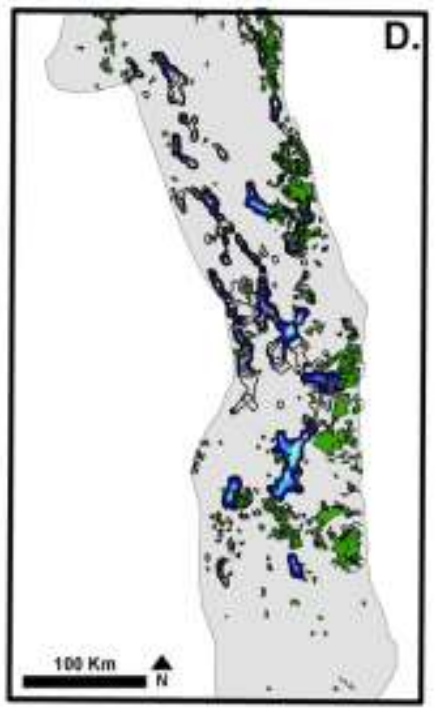

Conductance

9800.00

25.00

Forest Remnants

1220 Fig. 5. Maps of landscape resistance models for amphibian ecological connectivity

1221 between forest remnants in the Central Corridor of the Brazilian Atlantic Forest. Null

1222 model for isolation-by-distance - IBD/IB3D (A), landscape model for isolation-by-

1223 resistance - IBR (B); landscape model for IBR showing the distribution of forest

1224 remnants with a frame in the highest conductance areas (C); zoom in the frame with

1225 high-conductance areas showing the potential landscape connectivity between patches with low resistance surface (D). 